\title{
PEMBERDAYAAN MASYARAKAT MELALUI PROGRAM CSR PT. ANGKASA PURA I YOGYAKARTA (STUDI KASUS UMKM MADU HUTAN RAYA DAN MINA KEMBAR)
}

\section{Community empowerment through CSR program PT. Angkasa Pura I Yogyakarta (Case study of UMKM in Madu Hutan Raya and Mina Kembar)}

\author{
Bayu Mahendra* \\ Program Studi Magister Agribisnis, Fakultas Pertanian, Universitas Pembangunan Nasional "Veteran" Yogyakarta, Yogyakarta, Indonesia \\ Doi: $10.37195 /$ jac.v1i2.62
}

\section{*KORESPONDENSI}

Telepon: +62 823-0002-5785

E-mail:vampirebiel@gmail.com

\section{JEJAK PENGIRIMAN}

Diterima: 12 Mar 2019

Revisi Akhir: 10 Jul 2019

Disetujui: 16 Jul 2019

\section{KEYWORDS}

Corporate social responsibility, Empowerment of MSMEs, Development

\section{KATA KUNCI}

Tanggung jawab sosial perusahaan, Pemberdayaan UMKM, Perkembangan

\begin{abstract}
This study aimed to (1) assessing the empowerment process through Corporate Social Responsibility (CSR) programs carried out by PT. Angkasa Pura I on Micro Small Medium Enterprises (2) assessing the development of MSMEs that utilize CSR programs. This research is a qualitative research with a method of carrying out case studies, taking informants purposively. Data collection techniques used are in-depth interviews, observation, and documentation while for the data analysis techniques using descriptive qualitative and the validity of the data obtained tested by triangulation of data collection techniques. The results of this study conclude that, (1) the process of empowerment through a CSR program implemented by PT. Angkasa Pura I on MSMEs, started from the capacity building phase and did not go through the awareness stage and (2) development of MSMEs utilizing CSR programs of PT. Angkasa Pura I had been running well which was marked by the beginning of the development of business assets and also business mindset.
\end{abstract}

Penelitian ini bertujuan untuk (1) mengkaji proses pemberdayaan melalui program CSR yang dilakukan PT. Angkasa Pura I terhadap Usaha Mikro Kecil dan Menengah (UMKM) dan (2) mengkaji perkembangan UMKM yang memanfaatkan program CSR. Penelitian ini merupakan penelitian kualitatif dengan metode pelaksanaan studi kasus, pengambilan informan secara purposive. Teknik pengumpulan data yang digunakan adalah wawancara mendalam, observasi, dan dokumentasi sedangkan untuk teknik analisis data menggunakan deskriptif kualitatif dan keabsahan data yang diperoleh diuji dengan triangulasi teknik pengumpulan data. Hasil penelitian ini memberikan kesimpulan bahwa, (1) proses pemberdayaan melalui program CSR yang dilaksanakan PT. Angkasa Pura I terhadap UMKM, dimulai dari tahap pengkapasitasan dan tidak melalui tahap penyadaran dan (2) perkembangan UMKM yang memanfaatkan program CSR dari PT. Angkasa Pura I sudah berjalan dengan baik yang ditandai dengan mulai berkembangnya asset usaha hingga pola berfikir dalam berusaha.

\section{PENDAHULUAN}

Pemberdayaan merupakan upaya untuk memandirikan masyarakat lewat perwujudan potensi kemampuan yang mereka miliki baik secara individu maupun kelompok. Konsep memandirikan meliputi kemandirian berpikir, bertindak, menghadapi dan mengendalikan apa yang mereka lakukan. Sedangkan menurut Korten (1984), pemberdayaan 
adalah peningkatan kemandirian rakyat berdasarkan kapasitas dan kekuatan internal rakyat atas sumberdaya manusia baik material maupun nonmaterial melalui redistribusi modal.

Pemberdayaan adalah sebuah proses dan tujuan. Sebagai proses pemberdayaan adalah serangkaian kegiatan untuk memperkuat kekuasaan atau keberdayaan kelompok lemah dalam masyarakat, termasuk individu-individu yang mengalami masalah kemiskinan. Sebagai tujuan, maka pemberdayaan merujuk pada keadaan atau hasil yang ingin dicapai oleh sebuah perubahan sosial, dimana masyarakat yang berdaya, memiliki kekuasaan, pengetahuan dan keterampilan hidupnya baik yang bersifat fisik, ekonomi maupun sosial seperti memiliki kepercayaan diri, mampu menyampaikan aspirasi, berpartisipasi dalam kegiatan sosial, dan mampu melaksanakan tugas-tugasnya.

Setiap UMKM tentunya memiliki harapan untuk dapat mengembangkan usaha menjadi lebih besar dan lebih baik, begitu juga pada UMKM Madu Hutan Raya dan Mina Kembar. Pada kenyataannya untuk dapat mengembangkan usahanya, UMKM harus kuat secara modal, inovasi dan SDM hal tersebut masih belum terlihat pada UMKM Madu Hutan Raya dan Mina Kembar. UMKM Madu Hutan Raya berdiri sejak tahun 2013 bergerak dalam bidang distribusi dan penjualan madu hutan, permasalahan modal membuat UMKM Madu Hutan Raya kesulitan dalam membeli bahan baku madu sehingga penjualan dan keuntungan yang didapat kurang maksimal. UMKM Mina Kembar berdiri tahun 2006 UMKM Mina Kembar memiliki 6 kolam ikan yang diusahakan untuk ikan lele dan gurameh, jumlah kolam yang tidak banyak membuat produksi ikan yang dihasilkan belum cukup untuk memenuhi biaya pakan dan operasional sehingga keuntungan yang diperoleh juga belum maksimal. Pada tahun 2015 kedua UMKM bersama mendapatkan modal dan pelatihan dari program CSR PT. Angkasa Pura I dan perlahan mulai menemukan solusi bagi permasalahan usaha masing-masing UMKM.

Untuk meningkatkan kesejahteraan sosial masyarakat pemerintah mencanangkan program CSR bagi perusahaan mulai tahun 2007 yang tertuang dalam Undang-Undang Nomor 40 Tahun 2007 Bab V pasal 74 ayat 1, yang menyebutkan bahwa perseroan yang menjalankan usahanya di bidang dan atau berkaitan dengan sumberdaya alam wajib melaksanakan tanggung jawab sosial dan lingkungan CSR. PT. Angkasa Pura I yang merupakan BUMN juga memiliki tanggung jawab untuk melaksanakan program CSR, hal ini diatur dalam PER-03/MBU/12/2016. Melalui program tersebut dirumuskan kembali mekanisme upaya peningkatan kesejahteraan sosial masyarakat yang melibatkan unsur perusahaan, masyarakat, dan pemerintahan desa, mulai dari tahap perencanaan, pelaksanaan, hingga pemantauan dan evaluasi. Melalui proses pemberdayaan partisipatif, kesadaran kritis, kemandirian masyarakat dan peran perusahaan, tujuannya untuk memberikan kontribusi pembangunan yang berkelanjutan, kesehatan, dan kesejahteraan sosial, dengan kata lain CSR PT. Angkasa Pura I dapat dijadikan sebagai salah satu sumber pembiayaan pembangunan masyarakat.

\section{METODE}

\section{Jenis dan Sumber Data}

Penelitian dilakukan di Ring I Bandar Udara Adisucipto yaitu daerah lingkungan kerja bandar udara (DLKR) Yogyakarta yaitu 7 hingga $15 \mathrm{~km}$ dari bandar udara dan ditujukan pada UMKM yang menjadi mitra PT. Angkasa Pura I.

Data yang dikumpulkan berupa catatan yang ditulis tangan, gambar, foto, objek, suara dan gerak tubuh (gesture). Sumber Data untuk mendukung penelitian ini dapat diperoleh dari dua sumber, yaitu data primer dan data sekunder. Data Primer, yaitu data yang diperoleh langsung dari sumbernya yaitu UMKM mitra maupun PT. Angkasa Pura I yang didapat melalui wawancara dan observasi secara langsung. Data Sekunder, yaitu data yang sudah ada dalam pengumpulannya, diperoleh dari instansi terkait dalam penelitian, yaitu laporan dan catatan program CSR PT. Angkasa Pura I.

Sumber data utama dalam penelitian kualitatif adalah kata-kata dan tindakan, selebihnya adalah data tambahan seperti dokumen dan lain-lain. Dalam penelitian ini, data sekunder yang dikumpulkan berupa dokumen yang berkaitan dengan gambaran program kemitraan PT. Angkasa Pura I serta 
data Mitra Binaan yang telah mengikuti pembinaan.

Dalam pemilihan informasi, dipilih 2 informan mitra binaan yang telah mengikuti kegiatan pembinaan dengan tujuan agar memperoleh informasi yang variatif dan menyeluruh. Data yang diperoleh di lapangan selanjutnya disajikan dengan mendeskripsikan temuan penelitian secara sistematis, faktual, dan akurat disertai dengan petikan hasil wawancara dengan tiap-tiap informan.

\section{Jenis Penelitian}

Jenis penelitian yang digunakan dalam penelitian ini adalah penelitian kualitatif. Menurut Neuman (2006), pendekatan kualitatif merupakan pendekatan yang memandang kehidupan sosial dari berbagai sudut pandang dan menjelaskan bagaimana masyarakat membentuk suatu konstruksi sosial. Penelitian kualitatif mendapatkan data dari berbagai orang-orang yang peneliti temui dan diteliti, yang selanjutnya disebut informan. Pendekatan kualitatif menjabarkan dan menginterpretasi datanya secara kompleks dalam bentuk cerita dengan memperhatikan detail dari tiap peristiwa. Pemilihan informan dalam penelitian ini tentunya berdasarkan pertimbangan-pertimbangan pada informan yang telah diketahui sebelumnya, yaitu pihak PT. Angkasa Pura I dan Mitra Binaan yang berada di sekitar wilayah PT. Angkasa Pura I. Kriteria informan PT. Angkasa Pura I adalah Pihak yang bersentuhan langsung pada subprogram PKBL yang diteliti, yaitu ketua dan staff divisi CSR PT. Angkasa Pura I.

\section{Metode Analisis}

Analisa data pada penelitian ini mengikuti data dari Miles dan Huberman (1994) yang menyatakan bahwa analisa data dilakukan secara interaktif melalui proses data reduction, data display, dan verification (Sugiyono, 2011).

Data Reduction. Merangkum, memilih halhal yang pokok dari jawaban masing-masing informan, memfokuskan pada hal-hal yang penting, dicari tema dan polanya dan memilih membuang yang tidak perlu.

Data Display. Penyajian data yang dapat dilakukan dalam bentuk uraian singkat, bagan, hubungan antar kategori dan sejenisnya dengan mengelompokkan jawaban dari tiaptiap informan berdasarkan tema yang sama.
Data Interpretation. Membuat kesimpulan yang diharapkan dapat menjawab masalah dan rumusan masalah dalam penelitian kualitatif masih bersifat sementara dan akan berkembang setelah penelitian.

Setelah melakukan pengumpulan informasi melalui observasi dan wawancara dengan para informan yaitu divisi CSR PT. Angkasa Pura I dan para Mitra Binaan PT. Angkasa Pura I, maka hal selanjutnya adalah melakukan data reduction. Reduksi data dilakukan untuk memilih informasi mana yang sesuai dan tidak sesuai dengan pernyataan penelitian, mengenai pelaksanaan pembinaan UMKM dalam Program Kemitraan PT. Angkasa Pura I, sebagai wujud tanggung jawab sosial perusahaan (CSR) serta dampaknya bagi para mitra binaan. Setelah informasi dipilih maka data disajikan, bisa dalam bentuk tabel, bagan ataupun uraian penjelasan atau yang disebut dengan data display. Tahap terakhir dalam analisa data ini adalah melakukan data interpretation yakni menarik kesimpulan berdasarkan informasi maupun data yang sudah diolah sebelumnya.

\section{HASIL DAN PEMBAHASAN}

Program CSR PT. Angkasa Pura I dikenal dengan PKBL (Program Kemitraan dan Bina Lingkungan) yang merupakan perwujudan tanggung jawab sosial PT. Angkasa Pura I. Program CSR ini ditujukan kepada masyarakat sekeliling Daerah Lingkungan Kerja Bandar Udara (DLKR) tetapi juga tidak menutup kesempatan bagi masyarakat wilayah lain yang ingin bergabung atau menjadi mitra binaan sesuai dengan ketentuan yang berlaku. Program ini bertujuan untuk menjadikan mitra binaan yang tangguh dan mandiri dalam mengelola usahanya serta meningkatkan kondisi sosial masyarakat. Lako (2011) menyatakan bahwa, CSR merupakan kewajiban asasi perusahaan yang tidak boleh dihindari. Dasar argumentasinya adalah bahwa perusahaan harus bertanggung jawab atas semua konsekuensi yang ditimbulkan, baik sengaja maupun tidak sengaja kepada para pemangku kepentingan. Program Kemitraan dan Bina Lingkungan PT. Angkasa Pura I dibiayai oleh Anggaran Perusahaan dan saldo dana yang berasal dari penyisihan laba BUMN yang teralokasi. Jeurissen (2000) menyatakan bahwa, CSR bermakna sebagai 
suatu komitmen perusahaan atau dunia bisnis untuk berkontribusi dalam pembangunan ekonomi secara berkesinambungan dengan menyelaraskan pencapaian kinerja ekonomi dengan kinerja sosial dan lingkungan dalam operasi bisnisnya.

Proses pemberdayaan pada program CSR PT. Angkasa Pura I diawali pada tahap pengkapasitasan dan tidak melalui tahap penyadaran. PT. Angkasa Pura I memberikan capacity building (tahap pengkapasitasan) berupa keahlian dan keterampilan kepada UMKM agar mampu mengembangkan usaha kearah yang lebih baik. Kuncoro (2006) mengungkapkan bahwa ada beberapa kendala yang dialami oleh UMKM dalam menjalankan usahanya. Kendala tersebut berupa tingkat kemampuan, ketrampilan, keahlian, manajemen sumber daya manusia, kewirausahaan, pemasaran dan keuangan.

Pengkapasitasan manusia berarti memampukan manusia baik secara individu maupun kelompok agar mampu menerima daya atau kekuasaan yang akan diberikan. Bentuknya dapat berupa pendidikan, pelatihan, seminar, workshop dan lain-lain (Wrihatnolo \& Dwidjowijoto 2007). Pengkapasitasan manusia dilakukan agar pelaku UMKM mampu menerima daya yang akan diberikan. Tahap pengkapasitasan terjadi pada saat pelatihan oleh PT. Angkasa Pura I dengan dibantu stakeholder lain yang bertujuan menguatkan UMKM dari segi manajemen, SDM dan pemasaran produk UMKM.

Tahap ketiga dari proses pemberdayaan adalah tahap pemberian daya yaitu pemberian kekuasaan kepada organisasi/masyarakat yang diberdayakan (Wrihatnolo \& Dwidjowijoto 2007). PT. Angkasa Pura I memberikan kekuasaan penuh terhadap tumbuh kembang UMKM yang memanfaatkan pinjaman lunak yang bertujuan agar UMKM dapat mengembangkan usahanya dengan menggunakan pinjaman lunak tersebut.

\section{Pandangan Perusahaan Terhadap CSR}

Program CSR yang dilaksanakan pihak PT. Angkasa Pura I bertujuan untuk memajukan usaha milik masyarakat D.I. Yogyakarta, sehingga perekonomian di Yogyakarta pun berkembang. Latar belakang perusahaan dalam melaksanakan program CSR salah satunya adalah sebagai bentuk realisasi dari salah satu misi perusahaan, yaitu turut berkontribusi dalam menumbuhkan pendapatan masyarakat. PT. Angkasa Pura I memiliki harapan yang besar kepada UMKM yang telah mengikuti proses pelatihan yang diberikan. UMKM yang kuat dari berbagai segi, adalah tujuan dari program CSR ini, sehingga nantinya UMKM inilah yang akan membangkitkan perekonomian masyarakat. UMKM yang telah mengikuti pelatihan diharapkan dapat mengelola pinjaman lunak yang diberikan PT. Angkasa Pura I kepada UMKM. PT. Angkasa Pura I juga membantu UMKM dalam mempromosikan dan memasarkan produk UMKM melalui etalase dan stand khusus di Bandara, hal ini dilakukan agar produk UMKM dapat dikenal dan dilihat banyak orang, sehingga peminat produk UMKM bertambah.

Dalam proses pelatihan yang dilakukan, PT. Angkasa Pura I menggandeng pihak akademik, yaitu Univesitas Gadjah Mada (UGM). Hal ini diperlukan agar materi dari pelatihan yang dilaksanakan benar-benar tepat dengan apa yang dibutuhkan oleh UMKM. Selain UGM, PT. Angkasa Pura I juga menggandeng pihak Bank yaitu Bank Rakyat Indonesia (BRI), dalam hal ini pihak BRI akan membantu membuatkan autodebet kepada UMKM sehingga memudahkan UMKM dalam mengangsur pinjaman.

Suharto (2007) menyatakan bahwa CSR merupakan operasi bisnis yang berkomitmen tidak hanya untuk meningkatkan keuntungan perusahaan secara finansial, melainkan pula untuk pembangunan sosial ekonomi kawasan secara holistik, melembaga dan berkelanjutan.

\section{Hasil Pemberdayaan Program CSR PT. Angkasa Pura I Kepada UMKM}

Hasil Pemberdayaan program CSR PT. Angkasa Pura I terhadap UMKM, dapat dilihat pada kemandirian permodalan, di mana terlihat peningkatan asset yang dimiliki oleh UMKM tersebut.

Madu Hutan Raya, pada UMKM ini masih terlihat jelas kesederhanaan dalam pengelolaan usahanya. Usaha yang berdiri sejak tahun 2013 ini bergerak dalam bidang distribusi dan penjualan madu hutan, dimana madu hutan curah yang dibeli dari Provinsi Riau dan NTT dipilah berdasarkan kualitas lalu dilakukan pengemasan ulang menjadi berbagai kemasan 
dengan merk Madu Hutan Raya yang merupakan merk milik Bapak Waluyo sendiri. UMKM Madu Hutan Raya dalam memasarkan produknya menggunakan kendaraan yang dikemudikan sendiri oleh Bapak Waluyo selaku pemilik UMKM dan dilakukan secara berpindah-pindah lokasi.

UMKM yang beralamat di Kabupaten Sleman ini belum meliliki arah pengembangan usaha yang baik. Setelah menjadi mitra binaan PT. Angkasa Pura I, perlahan tapi pasti, Bapak Waluyo selaku pelaku UMKM mengatakan bahwa pelatihan yang dilakukan oleh PT. Angkasa Pura I dalam program CSR-nya sangat membantu dalam hal mengembangkan jiwa, keterampilan, dan wawasan sebagai pengusaha. Pelatihan yang kala itu dilaksanakan di Grand Quality Hotel telah menginspirasi beliau untuk mengembangkan produknya, yaitu Madu Hutan. Menjadi mitra binaan PT. Angkasa Pura I juga menambah pengetahuan bagi Bapak Waluyo mengenai berbagai usaha UMKM yang ada di Yogyakarta, sehingga semangat berwirausaha akan semakin besar.

Pada UMKM Mina Kembar yang terletak di dusun Candi Singo, desa Madurejo,
Kecamatan Prambanan ini, hal yang sangat diperlukan adalah permodalan untuk pengembangan usaha. Bertemu langsung dengan Ibu Valentina selaku pemilik UMKM Mina Kembar yang mengatakan bahwa sebelum bermitra dengan PT. Angkasa Pura I, usaha perikanan milik beliau dirasa belum optimal, hal ini terkendala oleh skala usaha yang masih kecil sehingga apabila dituntut oleh pedagang untuk kontinyu, beliau masih kesulitan.

Pada tahun 2015, saat beliau diberi tahu oleh pihak PT. Angkasa Pura I yang kebetulan sedang melakukan program Bina Lingkungan di Puskesmas Madurejo, Ibu Valentina langsung berminat untuk bermitra dengan PT. Angkasa Pura I, mengingat kebutuhan beliau dalam hal pengembangan usaha perikanan. Berdiri dari tahun 2006, UMKM Mina Kembar memiliki 6 kolam ikan yang diusahakan untuk ikan lele dan gurameh. Setelah bermitra dengan PT. Angkasa Pura I beliau menambah jumlah kolam menjadi 12 kolam, hal ini tentunya merupakan perkembangan yang sangat didambakan oleh Ibu Valentina selaku pemilik UMKM.

Tabel 1. Proses kemandirian UMKM

\begin{tabular}{lll}
\hline $\begin{array}{l}\text { Kemandirian dalam pola pikir } \\
\text { dan pola kerja }\end{array}$ & $\begin{array}{l}\text { Kemandirian dalam mengelola } \\
\text { usaha }\end{array}$ & Kemandirian dalam sistem \\
\hline $\begin{array}{l}\text { Menentukan pilihan produk } \\
\text { yang akan di usahakan sendiri }\end{array}$ & $\begin{array}{l}\text { Usaha yang mengedepankan profit } \\
\text { Mampu mengakses pasar yang lebih }\end{array}$ & $\begin{array}{l}\text { Menambah asset usaha yang } \\
\text { sudah ada }\end{array}$ \\
$\begin{array}{l}\text { Menentukan arah } \\
\text { pengembangan usaha sendiri }\end{array}$ & luas & $\begin{array}{l}\text { Mempunyai rasa percaya diri } \\
\text { Sikap kewirausahaan yerusaha }\end{array}$ \\
tumbuh & untuk menjadi modal & Mampu memasarkan produk dengan \\
& baik & $\begin{array}{l}\text { Rasa optimis dalam } \\
\text { melangkah kedepan dan } \\
\text { mengambil resiko }\end{array}$ \\
\hline
\end{tabular}

Dari Tabel 1, proses pemberdayaan PT. Angkasa Pura I melalui program CSR yang diperuntukkan kepada UMKM dapat dikatakan telah berhasil. Keberhasilan proses pemberdayaan dapat dilihat dari kemandirian pola pikir dan pola kerja di mana UMKM telah dapat menentukan pilihan produk, arah pengembangan usaha, dan juga sikap kewirausahaan yang mulai tumbuh. Dalam kemandirian mengelola usaha, UMKM Mina Kembar dan Madu Hutan Raya juga mengalami peningkatan, yaitu usaha yang dijalankan telah mengedepankan profit (keuntungan), UMKM telah mampu mengakses pasar yang lebih luas. Kedua UMKM sebelum mengikuti program CSR hanya mampu menjangkau daerah sekitar UMKM (lingkup kecamatan), setelah mengikuti program CSR, UMKM mampu menjangkau pasar di lintas kabupaten bahkan pasar provinsi, mampu mengembangkan profit untuk dijadikan tambahan modal, dan mampu memasarkan produk dengan lebih baik. Pada kemandirian dalam sistem pun UMKM mengalami peningkatan, yaitu asset 
usaha yang bertambah, rasa percaya diri dalam berusaha meningkat, dan rasa optimis dalam melangkah kedepan dan mengambil resiko juga meningkat. Hal tersebut tentu saja dapat mendorong laju pembangunan ekonomi dan sosial masyarakat. Pembangunan merupakan segala upaya yang terus-menerus, ditujukan untuk memperbaiki kehidupan masyarakat dan bangsa yang belum baik, atau untuk memperbaiki kehidupan yang sudah baik menjadi lebih baik lagi (Murdikanto, 2013).

\section{Tahap Pemberdayaan}

Tahap pemberdayaan yang terjadi dapat dilihat pada Tabel 2.

\section{Tahap Pemberdayaan}

Tidak ada tahap penyadaran yang berisi pemberian arahan, motivasi terhadap UMKM sebelum dilakukan pelatihan. Hal ini dikarenakan PT. Angkasa Pura I menggabungkan proses pemberian motivasi dan pemahaman tentang usaha pada tingkatan pelatihan.

Tabel 2. Tahapan Pemberdayaan

\begin{tabular}{ll}
\hline Proses & Penjelasan \\
\hline Tahap pertama, penyadaran & Tidak ada tahap penyadaran \\
\hline $\begin{array}{l}\text { Tahap kedua, } \\
\text { pengkapasitasan (Capacity }\end{array}$ & Mampu mengembangkan profit untuk menjadi modal \\
buildings) & PT. Angkasa Pura I memberikan kapasitas atau kemampuan dan \\
& keterampilan pada UMKM yang mengikuti program CSR: \\
& - Memberikan Pelatihan dasar bisnis \\
& - Memberikan pelatihan manajemen bisnis \\
& - PT. Angkasa Pura I memberikan pinjaman lunak untuk menambah \\
& modal sehinga UMKM dapat mengembangkan usahanya \\
\hline Tahap ketiga, pendayaan & PT. Angkasa Pura I memberikan kekuasaan penuh UMKM untuk \\
atau pemberian daya & mengaplikasikan hasil pelatihan dan menggunakan dana pinjaman untuk \\
& mengembangkan usahanya kearah yang mereka tentukan sendiri. \\
\hline
\end{tabular}

\section{Pengkapasitasan}

Pengkapasitasan (capacity building) merupakan upaya PT. Angkasa Pura I dalam memberikan kapasitas atau kemampuan dan keterampilan pada UMKM yang mengikuti program CSR agar mampu melakukan usaha dengan sebaik-baiknya. Bentuk usaha meningkatkan kapasitas atau pengkapasitasan, yakni dengan pengkapasitasan manusia.

Pengkapasitasan manusia yang diberikan oleh PT. Angkasa Pura I kepada UMKM adalah pelatihan dasar bisnis hingga pelatihan memasarkan produk. Tujuan PT. Angkasa Pura I memberikan pengkapasitasan dengan pelatihan tersebut adalah untuk memperkuat UMKM dari sisi sumber daya manusia. PT. Angkasa Pura I membuat sebuah modul pelatihan yang di dalamnya memuat keseluruhan kegiatan pelatihan hingga inspirasi dari berbagai sumber.

\section{KESIMPULAN}

Proses pemberdayaan melalui program CSR yang dilaksanakan PT. Angkasa Pura I kepada UMKM, dimulai dari tahap pengkapasitasan dan tidak melalui tahap penyadaran. Perkembangan UMKM yang memanfaatkan program CSR dari PT. Angkasa Pura I sudah berjalan dengan baik yang ditandai dengan mulai berkembangnya aset usaha hingga pola berfikir dalam berusaha.

\section{SARAN}

Dalam penyusunan program CSR, dapat dilakukan dengan melibatkan calon penerima manfaat agar terjadi kesinambungan dalam program. Aset usaha yang meningkat seharusnya diimbangi dengan peningkatan kualitas produk sehingga dapat lebih memuaskan konsumen. Peningkatan produk 
yang terjual juga harus dimanfaatkan untuk menambah inovasi produk baru agar dapat diminati kalangan yang berbeda.

\section{DAFTAR PUSTAKA}

Jeurissen, R. (2000). John Elkington, Cannibals with forks: The triple bottom line of 21st century business. Journal of Business Ethics, 23(2), 229-231.

Korten, D. C. (1984). Pembangunan yang Memihak Rakyat: Kupasan Tentang Teori dan Metode Pembangunan, dialihbahasakan oleh Lembaga Studi Pembangunan (LSP). Jakarta: Yayasan Studi Pembangunan.

Kuncoro, M. (2006). Ekonomi Pembangunan (Teori, Masalah, dan kebijakan), ed. Keempat. Yogyakarta: UPP STIM YKPN.

Lako, A. (2011). Dekonstruksi CSR dan Reformasi Paradigma Bisnis dan Akuntansi. Jakarta: Erlangga.

Mardikanto, T. (2013). Pemberdayaan
Masyarakat oleh Perusahaan: Corporate Social Responsibility: Acuan bagi Praktisi, Akademisi, dan Pemerhati Program CSR. Surakatra: Sebelas Maret University Press.

Miles, M. B., \& Huberman, A. M. (1994). Qualitative Data Analysis: An Expanded Sourcebook (2nd ed.). SAGE Publications.

Neuman, W. L. (2006). Social Research Methods: Qualitative and Quantitative Approaches. Pearson/Allyn and Bacon.

Sugiyono. (2011). Metode Penelitian Kuantitatif, Kualitatif, dan $R \& D$. Bandung: Alfabeta.

Suharto, E. (2007). Pekerjaan Sosial di Dunia Industri: Memperkuat CSR (Corporate Social Responsibility). Bandung: Refika Aditama.

Wrihatnolo, R. R., \& Dwidjowijoto, R. N. (2007). Manajemen Pemberdayaan: Sebuah Pengantar dan Panduan untuk Pemberdayaan Masyarakat. Jakarta: PT. Elex Media Komputindo. 